\title{
Monetary Policy, Macroprudential Regulation and Inequality
}

\section{Pierre Monnin}

April 2017

Discussion Note 2017/2 
ABSTRACT

The 2008 global financial crisis profoundly changed the role of central banks in the economy. First, central banks engaged in strong expansionary monetary policy, using new unconventional tools to boost economic activity. Second, they were key to containing financial instability, which led them to implement new macroprudential policies to foster future financial stability. The debate about whether these policies have been effective is still ongoing, and often neglects two other crucial issues: What has been the impact of these policies on income and wealth distribution? Does inequality of income and wealth affect whether central bank policies reach their targets?

This note highlights research on these two questions presented during a CEP IMF workshop on "Monetary Policy, Macroprudential Regulation and Inequality" and puts them into perspective with other recent theoretical and empirical results. Evidence shows that monetary policy and macroprudential regulation are not neutral in terms of income and wealth distribution. Conventional and unconventional expansive monetary policy both appear to decrease income inequality, mainly through their impact on the labor market, and to increase wealth inequality. Theoretically, macroprudential regulation could also affect inequality, but empirical studies exploring this hypothesis are scarce.

Income and wealth distribution also influences the transmission of monetary policy impulses to the aggregate economy. To design effective monetary policy, it is crucial to assess whether the current income and wealth structures in a country accentuate or dampen monetary impulses, and to what extent they do so. Moreover, theoretical and empirical evidence points to an effect of inequality on financial stability. A thorough understanding of this impact is key to shaping optimal monetary policy and macroprudential regulation. 
ABOut THE Author

Pierre Monnin is a fellow with the Council on Economic Policies (CEP), where his work focuses on the distributive effects of monetary policy and on the role that central banks can play in the transition toward an environmentally sustainable economy. Before that, he was with the Swiss National Bank (SNB) in various roles for 10 years, counselling SNB's board members on issues concerning financial markets and monetary policy as well as developing measures of financial stability and integrating them into the bank's monetary policy framework. He also worked at Man Group as a quantitative analyst, developing asset allocation strategies for alternative investments. Dr. Monnin holds a PhD in economics from the University of Zurich, an MSc in economics from Queen Mary University of London, as well as an MSc in statistics and a BA in economics from the University of Neuchatel.

\section{CEP Discussion NOTES}

CEP Discussion Notes are published by the Council on Economic Policies (CEP), an international economic policy think tank for sustainability focused on fiscal, monetary and trade policy. The views expressed in these publications are those of the authors and do not necessarily represent those of CEP or its board. Discussion notes describe policyrelated analysis and research, and are published to elicit comments and further debate. 
CONTENTS

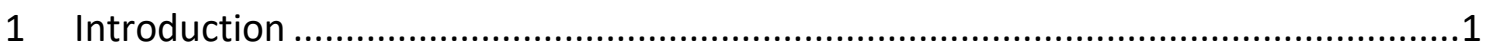

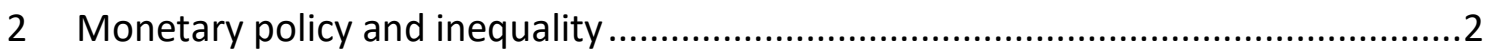

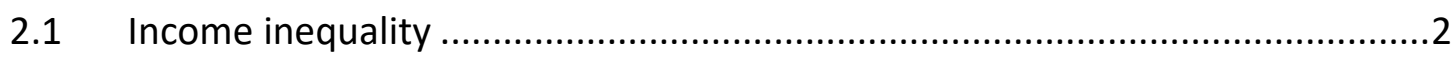

Channels from monetary policy to income inequality ................................. 2

Conventional monetary policy .............................................................. 4

Unconventional monetary policy ............................................................... 5

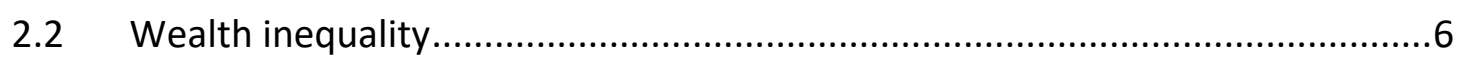

Asset prices and wealth inequality .......................................................... 6

Monetary policy and wealth inequality......................................................... 7

2.3 Inequality and the transmission of monetary policy ....................................

Channels through which inequality affects monetary policy transmission ...... 7

Inequality and monetary policy transmission: empirical evidence.................. 9

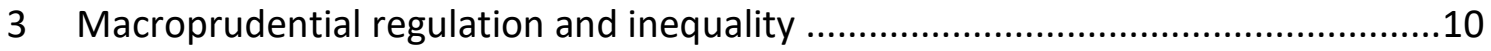

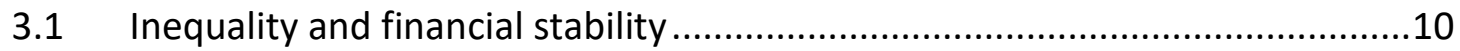

3.2 Impact of macroprudential measures on inequality ....................................11

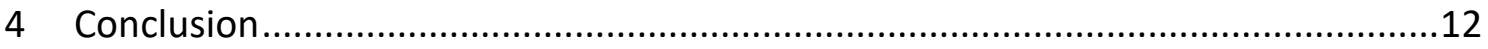

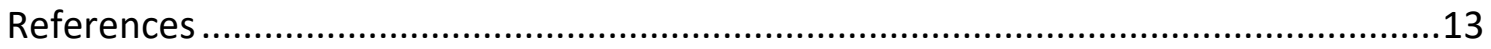


1 INTRODUCTION

Since the 2008 global financial crisis, the role of central banks in the economy has significantly increased. Major central banks have engaged in waves of expansionary monetary policy to boost economic activity and employment: first using conventional policy (by lowering shortterm interest rates), and then using more unconventional measures (new tools such as asset purchase programs and (targeted) long-term refinancing operations). During the crisis, they were also crucial in containing financial instability; in its aftermath, financial stability has been a predominant concern for them. Safeguarding financial stability is now widely accepted as part of central banks' responsibility.

The debate about whether unconventional monetary policy has been effective in boosting economic activity and employment is still ongoing, and often neglects another crucial issue: What has been the impact of these policies on income and wealth distribution? Did they reduce inequality by supporting low-income households, or did they contribute to the increasing inequality that has been observed in several countries since the 1980s?

The same questions apply to the impact of macroprudential policies implemented by central banks to foster financial stability. Do their potential gains (lower financial risk and/or better insurance) reach all or benefit only a few? Moreover, growing evidence points to inequality as a potential source of financial instability. Do central banks adequately reflect the possible impact of inequality on financial stability in designing macroprudential policies?

This note highlights key insights on these issues presented at a workshop on "Monetary Policy, Macroprudential Regulation and Inequality", co-organized by the Council on Economic Policies (CEP) and the International Monetary Fund in Zurich in October 2016. It also builds on earlier workshops CEP co-organized on the topic with the Federal Reserve Bank of Atlanta in 2014 and with the Federal Reserve Bank of St. Louis in 2015. ${ }^{1}$

Section 2 focuses on the links between conventional and unconventional monetary policies and inequality. Whether these policies increase or decrease inequality, and how significant these effects are, cannot be determined on a theoretical basis. Assessing the impact of central bank policies on income and wealth distribution is thus mainly an empirical question, which has long been overlooked. However, in recent years, central bank and academic researchers have started to examine this issue more closely. We present some of the most recent empirical findings in this field. We also highlight research on the effect of income and wealth structures on the transmission of monetary policy to the economy. Since propensities to consume vary with income, and income partly depends on each individual's wealth composition, different income and wealth distributions can significantly accentuate or

${ }^{1}$ See www.cepweb.org for further details. 
dampen aggregate reaction to monetary policy impulses. Accurately evaluating this effect requires taking income and wealth heterogeneity into account.

Section 3 presents theoretical and empirical findings on the ways inequality, macroprudential regulation and financial stability interact. Research on the connections between inequality and macroprudential policies is at an early stage. Nonetheless, existing analysis, both theoretical and empirical, offers interesting insights on this issue.

\section{MONETARY POLICY AND INEQUALITY}

"All monetary policy has distributional effects." - Mark Carney, Governor of the Bank of England, 2016

This section first focuses on the impact of monetary policies on income distribution, by presenting the transmission channels from monetary policy to income inequality and by summarizing recent evidence on this impact. It then turns to the analysis of the impact of monetary policies on wealth distribution, before focusing on the effects that inequality may have on the transmission channels and thus the overall effectiveness of monetary policy.

\subsection{INCOME INEQUALITY}

This subsection first explains how monetary policy can affect income inequality and then turns to empirical evidence. We distinguish between conventional and unconventional monetary policy shocks, since they do not interact with income inequality in the same ways.

\section{Channels from monetary policy to income inequality}

The impact of monetary policy on income inequality depends on the income and asset portfolio structures of the households in question. Household total income comes from two sources: labor and capital. ${ }^{2}$ Labor income is a function of labor supplied and of wages. Capital income is the income households earn out of their wealth, which mainly comprises deposits, bonds, equities, and property. It is a function of the returns on the different asset classes and of household portfolio composition. ${ }^{3}$

Monetary policy can affect income inequality through three main channels:

\footnotetext{
${ }^{2}$ In this note, we do not consider income earned from fiscal transfers; therefore, we focus on market income inequality rather than net income inequality.

${ }^{3}$ We define capital income as comprising interest on deposits, interest on bonds, rents from properties and dividends from stocks. Capital gains are not included in this definition, but reflected as a change in wealth in the subsequent section.
} 
- Income composition: The proportion of labor income and capital income in total income differs among households. If monetary policy changes one source of income relatively more than the other, this will alter income distribution. Low-income households tend to get a larger share of their income from labor, and thus they would be the relative winners from a monetary policy that boosts labor returns more than returns on capital.

- Labor income heterogeneity: Expansive monetary policy aims to stimulate economic activity and is thus likely to increase aggregate labor income. Some households might benefit relatively more than others from this increase. Empirical findings ${ }^{4}$ suggest that households at the bottom of the income distribution benefit the most from an increase in labor market activity, especially through a reduction in unemployment. Thus, an increase in labor market activity generated by expansionary monetary policy is likely to benefit low-income households more and consequently to reduce laborrelated income inequality.

- Capital income heterogeneity: Monetary policy does not have the same impact on the return of different assets. In addition, households do not all hold the same asset portfolio. The combination of heterogeneous asset returns and heterogeneous asset portfolios makes it difficult to assess the impact of monetary policy on capital income inequality. For example, low interest rates lower returns on bonds. Households with a large share of bonds will thus see their capital income decrease. However, since the beginning of the century returns on equities and bonds have repeatedly moved in opposite directions, implying that lower returns on bonds could be partly compensated for by higher returns on equities. ${ }^{5}$ These counterbalancing effects can theoretically induce either an increase or a decrease in capital income inequality, depending on the composition of household portfolios.

Since the crisis, central banks have pursued two kinds of expansive monetary policy: first, they used conventional tools by lowering short-term interest rates; then, they used unconventional monetary policy, such as quantitative easing. Since these policies do not work through the same channels, their impact on income inequality may also differ.

\footnotetext{
${ }^{4}$ See, for example, Heathcote, Perri and Violante (2010) for the United States between 1967 and 2006, or Bonhomme and Hospido (2016) for Spain between 1988 and 2010.

${ }^{5}$ See, for example, Roberts-Sklar (2016) for the correlation between bond and equity returns in the United Kingdom over the last 250 years, and Rankin and Shah Idil (2014) for the correlation in the United States since 1900. Both studies present results for equity returns including capital gains, whereas, in this note, we define equity return as dividends (i.e. without capital gains). However, since dividends are historically positively correlated with capital gains, both equity returns with and without capital gains have been negatively correlated with bond returns since the beginning of this century.
} 
Furceri, Loungani and Zdzienicka (2016) analyze the impact of conventional monetary policy shocks on income inequality in 32 advanced and emerging markets over the period from 1990 through 2013. They find that unexpected expansionary shocks reduce income inequality. They also estimate that this effect is economically significant, as an unexpected 100 -basis-point change in the policy rate induces a medium-term change of one standard deviation in the Gini index. Furthermore, they show that the impact of monetary policy is asymmetric: an unexpected increase in the policy rate raises income inequality more than a decrease reduces it. This asymmetry suggests that monetary policy shocks have a persistent impact on income inequality. The authors also provide insights into the relevance of the different channels through which monetary policy affects income inequality. Moreover, they highlight that the decrease in income inequality after an unexpected monetary policy expansion is greater in countries with a larger share of labor income. This suggests that it is the transmission of monetary policy shocks through the labor income heterogeneity channel and/or the income composition channel, that affects income inequality.

A decrease in income inequality resulting from expansionary conventional monetary policy is also observed by Guerello (2016) in the euro area from 1999 to 2015. Guerello's study, together with Furceri et al., confirm the findings of Coibion, Gorodnichenko, Kueng and Silvia (2016) in the United States and Mumtaz and Theophilopoulou (2016) in the United Kingdom. All four studies find that expansionary conventional monetary policy decreased income inequality, and that the contribution of monetary policy to changes in income inequality was economically significant. The latter two studies emphasize the importance of the labor income heterogeneity channel as a driver of this effect.

O'Farrell and Rawdanowicz (2016) focus on the impact of an interest rate change on income inequality through changes in fixed-income returns and in debt servicing, thus excluding its effect on the labor market, real estate returns and equity returns. Their analysis is based on income and wealth structures for Canada, some euro area countries, the United Kingdom and the United States. They find that a one-percentage-point interest rate reduction lowers income inequality in Canada, the United States and around half of the euro area countries they study, but increases it in the United Kingdom and the other euro area countries. This divergence reflects differences in the distribution of interest-paying assets and total debt across income deciles. Overall, they find that lower interest rates have a limited impact on income inequality through changes in fixed-income return and debt servicing, which is an additional sign that the significant impact of conventional expansive monetary policy on income inequality, found in the studies mentioned above, is linked to its effect on labor income. 
The empirical findings on the distributive impact of unconventional monetary policy so far are not clear-cut: some studies find that unconventional monetary policy has increased income inequality, ${ }^{6}$ while others point to a counter-factual scenario and argue that unconventional monetary policy has dampened a significant increase in income inequality that would have happened without a reaction from central banks. ${ }^{7}$

Casiraghi, Gaiotti, Rodano and Secchi (2016) investigate the impact of the European Central Bank's (ECB's) unconventional monetary policy on income inequality in Italy. They compare three different accommodative policies: (1) a combination of government bond purchases, liquidity injections and announcements on open-market transactions, which correspond to the actions taken by the ECB in 2011 and 2012, (2) an asset purchase program and (3) a reduction in official interest rates. The first two alternatives correspond to unconventional monetary policy and the latter to conventional policy. Using a model of the Italian economy, they calibrate the three different monetary policy inputs that are required to get the same increase in real GDP and compare their distributive consequences. This methodology disentangles the distributive impacts of different monetary policies from their aggregate effect.

In all three scenarios, the authors find that expansionary monetary policy decreases labor income inequality by improving the labor income of low-income households more than that of high-income households, through the labor income heterogeneity channel. This decrease in labor income inequality is largely, but not completely, compensated for by an increase in capital income inequality through the capital income heterogeneity channel. When the income composition channel is also taken into account, the simulated impact of all three expansionary monetary policies on income-inequality indices is statistically not significant. Casiraghi et al. also find that conventional and unconventional policies that generate similar aggregate stimulus in the Italian economy do not have markedly different impacts on income inequality.

Guerello also looks at the impact of unconventional monetary policy used by the ECB on income inequality. In contrast to Casiraghi et al., she uses historical data and a vector autoregressive model. She finds that unconventional monetary policy has a long-run effect on asset prices. She also highlights evidence of an increase in income inequality in the short run after expansionary unconventional monetary policy. However, in the long run, this effect is more than offset, and income inequality decreases.

Both studies show that the distributive effects of unconventional monetary policy might not differ significantly from those of conventional monetary policy, but this conclusion must be

${ }^{6}$ See, for example, Montecino and Epstein (2015) for the United States, Mumtaz and Theophilopoulou (2016) for the United Kingdom and Saiki and Frost (2014) for Japan.

${ }^{7}$ See, for example, Bivens (2015) for the United States and Bank of England (2012) for the United Kingdom. 
taken with a pinch of salt, since both studies come with some methodological caveats. Casiraghi et al.'s results rely on the assumption that the impacts of monetary policy on Italian economic and financial variables are measured accurately by their structural model. Guerello's results rely on qualitative measures of income inequality and on a methodology to identify monetary policy shocks that is subject to debate.

\subsection{WEALTH INEQUALITY}

Household wealth comprises mainly deposits, bonds, equities and property, from which debts are deducted to determine household net wealth. Monetary policy affects household wealth through its impact on the prices of these different components. Since household balance sheet structures differ, monetary policy is likely to have a heterogeneous impact on household wealth. Whether monetary policy increases or decreases wealth inequality depends both on its different impacts on asset prices and on the different balance sheet structures of households.

In this section, first, we present recent empirical findings on the link between asset price movements and wealth inequality; then, we focus on the impact of both conventional and unconventional monetary policy on wealth inequality through its impact on asset prices.

\section{Asset prices and wealth inequality}

Adam and Tzamourani (2016) provide a detailed estimation of the distributional consequences of asset price changes for the euro area. They find different impacts on inequality for different assets: capital gains in bonds and equities benefit only a quarter of the population. Winners from capital gains in bonds are spread evenly across both the income and wealth distributions; thus, capital gains in bonds do not have a material impact on inequality. Winners from capital gains in equities are highly concentrated in the top five per cent of the income and wealth distributions; increases in equity prices thus lead to higher inequality. Increases in housing prices benefit a much larger part of the population than increases in bond and equity prices. Capital gains from housing are concentrated among the middle and upper middle class of wealth distribution. With these parts of society accounting for more than $50 \%$ percent of the total population, increases in housing prices thus decrease wealth inequality somewhat. O'Farrell and Rawdanowicz (2016) find relatively similar results for the euro area, the United States, the United Kingdom and Canada: increases in housing prices tend to reduce wealth inequality, increases in stock and bond prices tend to increase it. 
Monetary policy and wealth inequality

Adam and Tzamourani (2016) estimate the impact of both conventional and unconventional monetary policy on wealth inequality in the euro area. For conventional monetary policy, they find that an unexpected decrease in the monetary policy rate leads to disproportionately large capital gains at the top end of the wealth distribution: the richest five per cent of households gain on average about five times as much as the remaining 95 per cent of households, mainly through capital gains in equity. To gauge the impact of unconventional monetary policy on wealth inequality, Adam and Tzamourani (2016) focus on asset price movements during ECB's Outright Monetary Transactions announcements over the summer of 2012. They find that these announcements had an impact similar to an unexpected 175-basis-point decrease in the policy rate. The announcements' distributive impact was qualitatively similar to conventional monetary policy - i.e. disproportionately large capital gains at the top end of the wealth distribution, mainly through equity capital gains.

Casiraghi et al. (2016) compare the impact of the ECB's conventional and unconventional monetary policy on wealth inequality in Italy. They find that all three types of accommodative monetary policy, as described earlier, induce a U-shaped distribution of changes in wealth: households at the bottom and at the top of the wealth distribution gain the most from accommodative monetary policies. Overall, Casiraghi et al. find that the effects of both conventional and unconventional monetary policy on wealth are statistically negligible.

\subsection{INEQUALITY AND THE TRANSMISSION OF MONETARY POLICY}

Whether monetary policy significantly contributes to inequality is still subject to debate. What is less contested is that inequality affects the transmission of monetary policy to the aggregate economy. This section first highlights the principal channels through which income and wealth distributions affect monetary policy transmission and then turns to recent empirical studies of this phenomenon.

\section{Channels through which inequality affects monetary policy transmission}

Income and wealth inequality can affect the transmission of monetary policy through three main channels:

- Heterogeneous propensities to consume: Households have different propensities to spend additional income from monetary policy impulses. The higher a household's propensity to consume, the stronger its additional demand resulting from monetary 
expansion. If the propensity to consume is correlated with income or wealth levels, then the income and wealth structure of a population will partly determine the impact of monetary policy decisions on real economic activity. ${ }^{8}$

- Heterogeneous financial market conditions: a change in monetary policy can affect households differently depending on the refinancing and reinvesting conditions that they face on financial markets. For example, lower interest rates result in lower returns for lenders and lower debt repayments for borrowers. In theory, and if all households faced the same market rates, these two effects would cancel each other out on aggregate. In practice, lenders and borrowers might face different refinancing or reinvesting conditions in the markets and thus might be differently affected by changes in interest rates. Their reactions to monetary policy depend on their ability to roll over their debts or their investments to take advantage of interest-rate changes. ${ }^{9}$ If this ability is not the same for borrowers and for lenders, then knowing the net wealth profiles of a population is necessary to accurately forecast the impact of monetary policy decisions on the aggregate economy.

- Limited access to financial markets: Monetary policy affects aggregate demand through changes in prices (or equivalently, changes in interest rates) on financial markets. Households adapt their consumption and investment patterns to these price changes, which then translate into an aggregate effect on the economy. However, in many countries, a significant part of the population has only limited access to financial markets. They might, for example, have access to only a limited set of financial products or be unable to trade frequently to rebalance their portfolio. Since such groups are unable to react fully to asset price changes, they are only indirectly affected by monetary policy decisions. This impedes or slows down the transmission of monetary policy to the economy. The larger the population with limited access to financial markets, the less effective the monetary policy transmission. In practice, income and wealth are major determinants of access to financial markets and, thus, the distribution of income and wealth matters in gauging the direct and indirect reactions of the economy to monetary policy impulses. ${ }^{10}$

\footnotetext{
${ }^{8}$ Auclert (2016) explores how heterogeneous marginal propensities to consume between winners and losers from interest-rate changes affect the transmission of a monetary impulse to aggregate demand. Using Italian and United States data, he finds that the redistribution channel of monetary policy through heterogeneous propensities to consume is as large as the traditional intertemporal substitution channel.

${ }^{9}$ Garriga, Kydland and Sustek (2015), for example, show that the transmission of monetary policy is stronger under adjustable mortgage rates than under fixed rates, because indebted households can adapt the value of payments on their outstanding debt.

${ }^{10}$ Galí, López-Salido and Vallés (2004) first showed that limited asset market participation alters the transmission of monetary policy to aggregate demand in a New Keynesian model and that optimal monetary policy must be adapted to reflect this fact. Bilbiie (2008) explores this hypothesis further and shows that the size of the excluded group matters in determining the size and the direction of the impact of monetary policy on the economy. Areosa and Areosa (2016) show that, when combined with heterogeneous labor productivity among households, limited financial market participation creates a link between inequality and inflation. This implies that a central bank aiming to control inflation must consider inequality in designing optimal monetary policy.
} 
Again, the different channels make it impossible to determine the impact of inequality on the effectiveness of monetary policy without turning to an empirical estimation.

\section{Inequality and monetary policy transmission: empirical evidence}

Doepke, Schneider and Selezneva (2015) investigate the impact of wealth distribution on the transmission channels for monetary policy using a model calibrated to data for the United States. They simulate a central bank announcement of a new target of a five per cent higher annual inflation rate over the next 10 years. They show that the responses of winners and losers from this announcement are different because they have different propensities to consume.

Guerello (2016) investigates the impact of income distribution on the transmission of monetary policy shocks in the euro area. She includes both monetary-policy and incomeinequality variables in a vector autoregressive (VAR) model to capture the impact of monetary policy shocks on aggregate consumption, both directly and indirectly through its impact on income distribution. She shows that consumption elasticity in response to both conventional and unconventional monetary policy shocks changes with income distribution. This change is relatively small for the elasticity in response to conventional monetary policy, but larger for the elasticity in response to unconventional monetary policy. The results are very heterogeneous across euro area countries and reflect the asset composition of wealth.

Voinea, Lovin and Cojocaru (2016) focus on the Romanian economy, which is characterized by relatively high income inequality in comparison with European standards. They find that households' responses to changes in interest rates depend on their income and indebtedness profiles. The transmission of monetary policy is more efficient for middle-income households, which are more indebted and have adjustable rates; lower policy rates ease their consumption constraints by lowering debt repayments. Lower-income households do not respond significantly to changes in policy rates because they have limited access to financial markets. Top-income households react to monetary policy less than middle-income households, because they are less indebted. This suggests that the decrease in debt repayments associated with lower interest rates is a key transmission channel of monetary policy to the economy in Romania.

These studies provide convincing evidence that inequality in income and wealth matters in understanding and gauging the reaction of the economy to monetary policy impulses. Central banks should thus take this dimension into account when designing and calibrating their policies. But they might also consider the level of inequality for another reason: changes in inequality might have an impact on the dynamics of economic growth. Auclert and Rognlie (2016) show that, when conventional monetary policy is constrained - for example, by reaching a lower bound - and when employment becomes the main equilibrating variable, a 
permanent rise in income inequality can lead to a permanent recession. ${ }^{11}$ Central banks should take this effect into account to design their best policy answer to worsening economic conditions.

\section{MACROPRUDENTIAL REGULATION AND INEQUALITY}

During the 2008 financial crisis, central banks played a crucial role in containing financial instability. In the aftermath of the crisis, safeguarding financial stability has been, explicitly or implicitly, widely acknowledged as part of their mandate. Several central banks have therefore endorsed a more proactive role in strengthening financial stability at the macroeconomic level, and some have implemented new macroprudential measures to pursue this goal. ${ }^{12}$

In this section, we first explore recent findings on the link between inequality and financial stability and then turn to evidence of how macroprudential measures can affect income and wealth inequality.

\subsection{INEQUALITY AND FINANCIAL STABILITY}

Several economists claim that increasing inequality might be a potential source of financial instability, by fueling imbalances on credit markets. Rajan (2010), for example, argues that rising inequality forced low- and middle-income households in the United States to borrow more than they reasonably should in order to maintain their relative consumption levels. This led to excess borrowing (i.e. credit bubbles), which, in turn, paved the way for the 2008 US financial crisis. Kumhof, Rancière and Winant (2015) support Rajan's claim with a theoretical model in which higher borrowing and economic crises are the endogenous result of highincome households having a growing share of income. Several empirical studies confirm the link between inequality and aggregate debt, some even pointing to inequality as a source of imbalances on the credit market. ${ }^{13}$ Hauner (2016) goes one step further and presents empirical evidence that, for countries with high levels of aggregate wealth, rising wealth inequality increases the likelihood of financial crises.

Mitkov (2016) provides noteworthy insights on how wealth inequality might also influence bank runs and their resolution. He shows that a government bailout policy during a systemic bank crisis is partly influenced by wealth inequality. Since official deposit guarantees tend to

\footnotetext{
${ }^{11}$ Ostry, Berg and Tsangarides (2014) provide international empirical evidence that higher inequality can increase the length of recessions. ${ }^{12}$ Cerutti, Claessens and Laeven (2015) compile the number of macroprudential measures used in 119 countries over the period 20002013. They show that, in advanced countries, the average number of macroprudential policies in place has doubled between 2007 and 2013.

${ }^{13}$ Perugini, Hölscher and Collie (2016) uncover a statistically significant, positive link between income inequality and private sector indebtedness in a panel of 18 OECD countries between 1970 and 2007. Van Treeck (2014) and Bazillier and Hericourt (2017) provide empirical evidence on the link between inequality and credit market bubbles.
} 
be more credible for poor households than for wealthy households, the latter are more prone to panic; the banks in which they invest are thus more likely to experience a run and receive a bailout. Consequently, bailouts tend to benefit wealthy investors at the expense of the general public.

All of these examples show that inequality and financial stability are intertwined and, thus, central banks should not neglect this dimension when designing macroprudential policies: macroprudential measures that ignore the impact of inequality on financial stability might miss a key determinant of financial fragility and thus might not have the intended effect. Punzi and Rabitsch (2016), for example, find that household wealth structure matters in designing countercyclical macroprudential measures. They show that optimal macroprudential policy should tighten excessive lending only for households that may react the most - i.e. deleverage - after a housing price shock. Such a policy improves individual and social welfare more than a macroprudential policy that targets all households uniformly.

\subsection{IMPACT OF MACROPRUDENTIAL MEASURES ON INEQUALITY}

Growing evidence shows that inequality might be a significant determinant of financial fragility; early evidence also indicates that macroprudential measures taken to foster financial stability might also have an impact on income and wealth inequality. Frost and van Stralen (2016) study the link between different types of macroprudential measures and income inequality in a panel of 69 countries over the period 2000 to 2013 . They find that countries with countercyclical capital buffers, concentration limits ${ }^{14}$ or limits on growth of direct credit tend to experience higher income inequality. By contrast, countries with special requirements for systemically important financial institutions have lower levels of income inequality. However, these results are based on correlation estimates, and the authors highlight that one cannot interpret their results as proving that macroprudential measures cause inequality.

Caps on loan-to-value (LTV) ratios are one example of a widely used macroprudential measure, but such caps affect households' access to mortgages and, since housing is the most important asset in most households' portfolio, relaxing or tightening this access may affect the distribution of wealth within a country. Carpantier, Olivera and Van Kerm (2016) show that, theoretically, caps on LTV ratios can increase or decrease wealth inequality depending on the underlying structure of the economy and, specifically, on the size of LTV ratios, on housing prices, on credit costs and on the intensity of inter-generational transfers. Using data on household balance sheets for 12 euro area countries, they estimate that

${ }^{14}$ Concentration limits restrain the fraction of assets held by a limited number of borrowers. 
wealth inequality among households with a mortgage increases when caps on LTV ratios become more stringent and decreases when housing prices increase.

4 CONCLUSION

Research shows that neither monetary policy nor macroprudential regulation are neutral in terms of income and wealth distribution. Theory, however, does not tell us whether they increase or decrease inequality; the answer to this question depends on the structure of the economy and, more particularly, on the structure of households' income and wealth. Whether monetary policy and macroprudential regulation increase or decrease inequality and whether their impact is economically significant is thus an empirical question.

Conventional and unconventional expansive monetary policy both appear to decrease income inequality, mainly through their impact on the labor market: low-income households benefit more from the increase in labor income following an expansionary monetary shock than high-income households. Evidence suggests that the impact of conventional and unconventional monetary policy does not differ significantly in terms of income inequality, but results for unconventional monetary policy are still at an early stage and subject to debate.

Evidence also indicates that conventional and unconventional monetary policy have the same impact on wealth inequality: they disproportionately benefit wealthy households, mainly through equity capital gains

Moreover, income and wealth distribution influences the transmission of monetary policy impulses to the aggregate economy. The papers presented above provide theoretical and empirical insights into this phenomenon. Assessing whether the current income and wealth structures in a country accentuate or dampen monetary impulses, and to what extent they do so, is thus crucial for the design of monetary policy. Taking this effect into account is key for central banks to provide the right monetary policy impulses.

Research on the impact of macroprudential regulation on inequality is scarcer. Theoretically, there are solid explanations of how macroprudential regulation can affect income and wealth distributions. Empirical evidence, however, is still at an embryonic stage.

Theoretical and empirical evidence also points to an effect of inequality on aggregate economic conditions and on financial stability. Incorporating this impact can help shape optimal monetary policy and macroprudential regulation. Central banks should pay attention to the potential feedback effects of their policies on inequality and, through it, on macroeconomic conditions and financial stability. This would help to avoid unintended consequences of their actions through changes in income and wealth distribution. 
REFERENCES

Adam, K. and P. Tzamourani (2016) "Distributional Consequences of Asset Price Inflation in the Euro Area." European Economic Review, 89, 172-192.

Areosa, W. D. and M. B. M. Areosa (2016) "The Inequality Channel Of Monetary Transmission." Journal of Macroeconomics, 48, 214-230.

Auclert, A. (2016) "Monetary Policy and the Redistribution Channel." Unpublished Paper. Auclert, A. and M. Rognlie (2016) "Inequality and Aggregate Demand." Unpublished Paper. Bank of England (2012) "The Distributional Effects of Asset Purchases." Bank of England Quarterly Bulletin, 2012Q3, 254-266.

Bazillier, R. and J. Hericourt (2017) "The Circular Relationship Between Inequality, Leverage, and Financial Crises." Journal of Economic Surveys, 31(2), 463-496.

Bilbiie, F. O. (2008) “Limited Asset Markets Participation, Monetary Policy and (Inverted) Aggregate Demand Logic." Journal of Economic Theory, 140(1), 162-196.

Bivens, J. (2015) "Gauging the Impact of the Fed on Inequality During the Great Recession." Working Paper No. 12. Hutchins Center on Fiscal and Monetary Policy at Brookings.

Washington, DC: Brookings Institute.

Bonhomme, S., and L. Hospido (2016) "The Cycle of Earnings Inequality: Evidence from Spanish Social Security Data." The Economic Journal, forthcoming.

Carney, M. (2016). “The Spectre of Monetarism." Roscoe Lecture, Liverpool John Moores University, December 5.

Carpantier, J.-F., J. Olivera and P. Van Kerm (2016). "Macroprudential Policy and Household Wealth Inequality." Unpublished Paper.

Casiraghi, M., E. Gaiotti, L. Rodano, and A. Secchi (2016) “A 'Reverse Robin Hood'? The Distributional Implications of Non-Standard Monetary Policy for Italian Households." Working Paper No. 1077. Rome: Bank of Italy.

Cerutti, E., S. Claessens and L. Laeven (2015) "The Use and Effectiveness of Macroprudential Policies: New Evidence." IMF Working Paper 15/61. Washington, DC: International Monetary Fund.

Coibion, O., Y. Gorodnichenko, L. Kueng and J. Silvia (2016) “Innocent Bystanders? Monetary Policy and Inequality in the U.S." Unpublished Paper.

Doepke, M., M. Schneider, and V. Selezneva (2015) “Distributional Effects of Monetary Policy." Unpublished Paper. 
Frost, J. and R. van Stralen (2016) "Macroprudential Policy and Income Inequality." Unpublished Paper.

Furceri, D., P. Loungani and A. Zdzienicka (2016) "The Effects of Monetary Policy Shocks on Inequality." IMF Working Paper No. WP/16/245. Washington, DC: International Monetary Fund.

Galí, J., J. D. López-Salido, and J. Vallés (2004) “Rule-of-thumb consumers and the design of interest rate rules." Journal of Money, Credit and Banking, 36(4), 739-763.

Garriga, C., F. E. Kydland and R. Šustek (2015) “Mortgages and Monetary Policy." Working Paper No. 751. Queen Mary University of London, School of Economics and Finance.

Guerello, C. (2016) “Conventional and Unconventional Monetary Policy vs. Households Income Distribution: an Empirical Analysis for the Euro Area." Unpublished Paper.

Hauner, T. (2016) “Aggregate Wealth and Its Distribution as Determinant of Financial Crises." Unpublished Paper. New York: City University of New York.

Heathcote, J., F. Perri, and G.L. Violante (2010) “Unequal We Stand: An Empirical Analysis of Economic Inequality in the United States, 1967-2006." Review of Economic Dynamics, 13(1), 15-51.

Kumhof, M., R. Rancière and P. Winant (2015) “Inequality, Leverage, and Crises." American Economic Review, 105(3), 1217-1245.

Mitkov, Y. (2016) "Inequality and Financial Fragility." Unpublished Paper. New Brunswick, NJ: Rutgers, the State University of New Jersey.

Montecino, J.A., and G. Epstein (2015) “Did Quantitative Easing Increase Income Inequality?" Working Paper No 28. New York: Institute for New Economic Thinking.

Mumtaz, H. and A. Theophilopoulou (2016) "The Impact of Monetary Policy on Inequality in the UK. An Empirical Analysis." Working Paper No. 783. Queen Mary University of London, School of Economics and Finance.

O'Farrell, R. and L. Rawdanowicz (2016) “Monetary Policy and Inequality: Financial Channels." Unpublished Paper. Organisation for Economic Cooperation and Development.

Ostry, J., A. Berg and C. Tsangarides (2014) “Redistribution, Inequality and Growth." IMF Staff Discussion Note 14/02. Washington, DC: International Monetary Fund.

Perugini, C., J. Hölscher and S. Collie (2016) “Inequality, Credit and Financial Crises." Cambridge Journal of Economics, 40(1), 227-257.

Punzi, M. T. and K. Rabitsch (2016) "Effectiveness of Macroprudential Policies under Borrower Heterogeneity." Unpublished Paper. 
Rajan, R. (2019) "Fault Lines: How Hidden Fractures Still Threaten the World Economy." Princeton, NJ: Princeton University Press.

Rankin, E., and M. Shah Idil (2014) "A Century of Stock-Bond Correlations." Reserve Bank of Australia Bulletin, September Quarter, 67-74.

Roberts-Sklar, M. (2016) "250 Years of the Bond-Equity Correlation." Blog. Bank Underground, Bank of England, October 20.

Saiki, A., and J. Frost (2014) “Does Unconventional Monetary Policy Affect Inequality? Evidence from Japan." Applied Economics, 46(36), 4445-4454.

van Treeck, T. (2014) “Did Inequality Cause the U.S. Financial Crisis?" Journal of Economic Surveys, 28(3), 421-448.

Voinea, L., H. Lovin, and A. Cojocaru (2016) “The Impact of Inequality on the Transmission of Monetary Policy." Unpublished Paper. 